\title{
The Sixth International Geological Congress: Zürich, 1894
}

1. Altwiesenstrasse 195, CH-8051 Zürich, Switzerland

2. Allmendboden 19, CH-Küsnacht, Switzerland

\begin{abstract}
In 1891, at the 5th International Geological Congress in Washington DC, it was suggested that Switzerland should host the 1894 Congress. Since Switzerland had not issued an official invitation for the 6th International Geological Congress, the Swiss geologists accepted somewhat reluctantly. The general lectures still concerned problems of classification. The most interesting discussions had to do with the structure of the Alps. The conference took place at a time between the first recognition of nappes and the general acceptance of their existence. The proponents of the nappe concept (Bertrand, Schardt; later Suess and Lugeon; modified versions: Rothpletz, Golliez) and the autochthonists (Heim, Baltzer; essentially also Renevier and Schmidt) opposed each other fiercely, before the question was finally resolved at the turn of the century.
\end{abstract}

\section{The structure of the Alps: state of the art in $\mathbf{1 8 9 4}$}

The Zürich Congress of 1894 was not one of the most important ones as far as scientific results were concerned, especially if compared to Bologna (1881) or Vienna (1903). Switzerland was the smallest country ever having the honour of organizing a session (Belgium, 1922 , was slightly smaller in $\mathrm{km}^{2}$, but had a larger population). The structure of the Alps and of other mountain chains was the centre of interest during the scientific meetings and particularly during the excursions (Figure 1). We shall devote most of our little paper to these discussions. This needs a short introduction to the problem, as it presented itself in 1894.

Dramatis personae (with their ages in 1894)

Eduard Suess, Vienna (63)

August Rothpletz, Munich (41)

Eugène Renevier, Lausanne (63)

Hans Schardt, Montreux and Lausanne (36)

Friedrich Mühlberg, Aarau (54)

Henri Golliez, Lausanne (34)

Armin Baltzer, Berne (52)

Carl Schmidt, Basel (34)

Marcel Bertrand, Paris (47)

Maurice Lugeon, Lausanne (24)

Albert Heim, Zürich (45)

The Zürich Congress took place ten years after Bertrand's famous paper on the Glarus Alps, in eastern Switzerland, one year after Schardt's demonstration of the 'exotic' nature of the Prealps in western Switzerland, and eight years before Lugeon's publication that announced the final breakthrough of the nappe concept. Views on the structure of the Alps were in a state of flux. The Prealpine story has been told by Masson (1976), the Glarus story by Trümpy (1991).

Thrusts had been noticed since the middle of the century, e.g. by Bernhard Studer (1853) and by Arnold Escher (1841). In the Glarus Alps, a spectacular thrust (recently proposed as part of the UNESCO Natural Heritage) carries Permian red-beds ('Verrucano') and their Mesozoic cover over Eocene to Lower Oligocene Flysch. Somehow, Escher recoiled from the consequences of his own observations, and he invented the strange hypothesis of the 'double fold': south- and north-facing recumbent anticlines facing each other across a narrow gap due to later, essentially Pleistocene, erosion.

Escher's disciple and successor Albert Heim $(1878,1891)$ took up his mentor's ideas and defended them vigorously, illustrating them by splendid drawings. The double fold came to be regarded as an objective 'truth' by almost all geologists. One of the few dissenters to this dogma was August Rothpletz (1883, 1894a, 1894b), who saw clear-cut, brittle thrusts instead of Heim's extremely laminated inverted limbs of folds. Heim (1895) did not accept any opposition and attacked Rothpletz in quite an unfair manner.

In 1884, Marcel Bertrand proposed that a single, north-facing nappe (which he still considered as an exaggerated over-fold) was far more plausible than the preposterous double fold. Rather cautiously, he extended this interpretation eastwards and especially westwards. Heim simply ignored Bertrand's paper, even after his

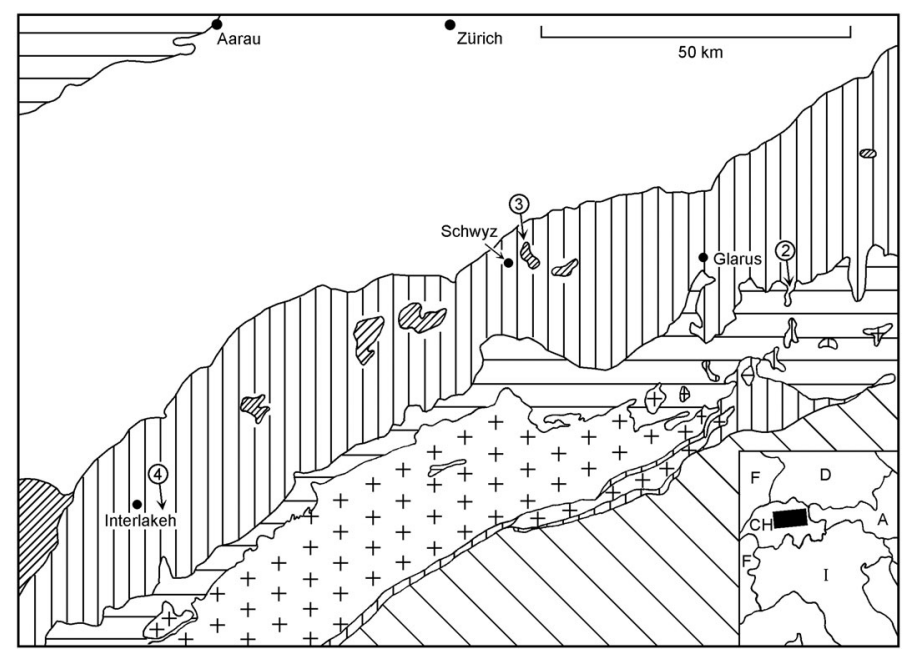

Figure 1 Simplified map of the tectonic units in part of Switzerland. 2, 3, 4 : Locations of the sections on Figures 2, 3, 4; Crosses: pre-Permian basement; Horizontal bars : Infrahelvetic cover rocks and Jura; Vertical bars : cover rocks of Helvetic nappes; Narrow oblique bars : outliers (klippen) of Penninic and (exceptionally) Austroalpine cover rocks; Wide oblique bars : Internal Zones of the Alps; White : Oligocene and Neogene of Molasse Basin; N.B. Penninic flysch nappes, on top of the Helvetic nappes, are grouped with these-as up to about 1910. 
friend Eduard Suess had visited the Glarus Alps in 1892 and had tried to convince Heim that Bertrand was right.

In the Prealps of western Switzerland, it became evident that the formations of the (present) Breccia nappe and the gypsum at the base of the (present) Médianes nappe were resting, all around, on Tertiary flysch. Once the Jurassic age of the first and the Triassic age of the second had been established, Hans Schardt (1893) concluded that both Médianes and Breccia were far-travelled nappes, derived from a 'root' way to the south, or at any rate beyond the external basement massifs (Aar, Montblanc). Schardt also recognized that some modest-sized mountains in central Switzerland, with Triassic and Jurassic rocks in the midst of a landscape of Cretaceous and Tertiary formations, were tectonic outliers (klippen in the present sense) of the Prealpine nappes. In his great 1898 paper, Schardt presented decisive arguments. Young Maurice Lugeon, who at first had been hesitant, became the most eloquent spokesman for the nappe concept; his 1902 paper made it widely known and accepted by most geologists.

This, then, was the situation in 1894 , on one side, the 'autochthonist' diehards, with their mushroom anticlines and tobacco-pouch synclines, facing both north and south (Heim and most of his followers, Baltzer, Renevier); on the other, there were the 'nappists', admitting only south-to-north displacement (Bertrand, Suess, Schardt, cautiously Lugeon with Golliez). Still others, like Carl Schmidt, tried to combine both views.

\section{Taken by surprise}

Up to the summer of 1891, the Swiss geologists did not suspect that they would have the honour and the burden of organizing the 6th International Geological Congress.

At the 5th Congress, in Washington DC, an invitation by the Russian delegation for the 7th Congress, in 1897, was received and gladly accepted, all the more as it was promised that "the generosity of H. M. the Tzar" would make it an unforgettable experience (see Milanovsky, 2004). It was expected that the Austrians would host the 6th session in 1894. But "for various reasons" they had to desist. The participants of the Washington Congress were thus at a loss to decide where to hold the 1894 meeting.

In private conversations and then in a more general discussion, Switzerland was mentioned. Flattery was successfully applied: Switzerland, with its spectacular geological sights and its good tourist infrastructure, was hailed as "the Mecca of all geologists". The official Swiss delegates at Washington, Henri Golliez and Carl Schmidt, were men in their early thirties and could not, of course, make a decision without consulting their Government and their senior colleagues.

The Swiss Government (the seven men of the Bundesrat) was taken aback and stated that it had never before received an invitation of this kind. The Federal Government was financially and politically rather weak - more power being held by the cantons (comparable to American states, though somewhat smaller). Furthermore, Switzerland did not have a Geological Survey until the 1970s, previous to which maps and some publications were edited by the Geological Commission, a group of university professors. However, the Government promised that it was willing to support its geologists if the Congress decided to honour the country by entrusting it to organize the 1894 Congress. This decision had been taken, still in Washington, on 1 September, 1891.

In the summer of 1891, most Swiss geologists were, as usual, abroad or doing fieldwork in the mountains so that they heard only by and by about what was ahead for them. Eventually, the officers of the Swiss Geological Society accepted the proposition of the Washington Assembly. An Organizing Committee, consisting of Armin Baltzer, Henri Golliez, Albert Heim, Friedrich Lang, Eugène Renevier, and Carl Schmidt, was nominated. They could co-opt additional members, choose the date, and select the location of the meeting. On 23 November, 1891, this committee and the members of the Geological Society met at Berne, where it was formally decided to accept the task of organizing the 6th Congress.

In a general discussion, the broad outlines of the programme were established. Renevier became President, Heim Vice-President and Golliez Secretary of the Organizing Committee. Zürich was chosen as a suitable place for the meeting and 29 August to 2 September, 1894, were settled as the dates. Special attention was devoted to the preparation of the excursions. An illustrated guide-book (livretguide; abbreviated $L G$ in the following) was to be published well before the session. For the latter, three sections were foreseen: (1) general geology, tectonics etc.; (2) stratigraphy and paleontology; (3) mineralogy and petrology. The official Congress language was to be French, but presentations in German were also to be accepted. A first circular was sent out in 1892, a second one early in 1894 .

The following years were full of activity by the organizers. Renevier and Heim exchanged more than a hundred letters (those written by Renevier are preserved in the ETH archives). Some of the correspondence mirrors the scientific tensions mentioned in Section 1. Thus, Eduard Suess was reluctant to present a lecture at Zürich and only accepted after several requests. Later, when asked to send a manuscript, he responded rather gruffly that there was no such thing, and that he did not have the time to write one. We may surmise that Suess did not want to confront Heim over the delicate question of the double-fold.

401 geologists registered: 95 from Germany; 65 from Switzerland; 43 each from France and Great Britain; 36 from Russia; and 35 from the United States. Only 273 of them actually attended the meeting, which was the lowest number since the first session of 1878 . Amongst all the beards and moustaches, there were two ladies; one of them, the Scotswoman Maria Ogilvie-Gordon, later wrote a remarkable monograph on the Dolomites of northern Italy.

\section{Scientific sessions}

There were six general lectures, by Zittel, Geikie, Michel-Lévy, Bertrand, Suess, and Heim - three in French, three in German. The Congress proceedings (Compte Rendu, abbreviated $C R$ in the following) were published in 1897. (The Scotsman Geikie had a French wife and was fluent in French.)

Karl Albert von Zittel (1839-1904), from Munich, was one of the greatest and certainly the most knowledgeable paleontologist of his time. His Handbuch der Paläontologie (1876-1893) was the standard reference work, based on a tremendous amount of study of all forms of fossil animals. His textbook, Grundzüge der Paläontologie (1895), went through many editions and was indispensable to geology students. Zittel (1899) also wrote a very well documented history of geology (which was later capably translated into English by Maria Ogilvie-Gordon). Zittel's working capacity must have been stupendous.

Zittel spoke on "ontogeny, phylogeny and systematics" $(C R$, 125-136). He noted the "definite breakthrough" of evolutionary theory, and he found the unravelling of phylogenetic relations to be the most rewarding task of paleontology". At the same time, he had a cautious approach to some over-optimistic concepts, such as Ernst Haeckel's (1834-1919) "fundamental biogenetic law" (ontogeny as a repetition of phylogeny). While acknowledging that the "old" (Linnean) systematics might lead to a sterile formalism (geistlose Verknöcherung), he still found it useful for describing the wealth of animal forms, and he maintained that the time was not yet ripe for a "new" classification along strictly phylogenetic lines.

Archibald Geikie (1835-1924, knighted 1907) was DirectorGeneral of H. M. Geological Survey. He worked mainly in Scotland. His book on The Founders of Geology (1897) is still readable, albeit 'Britannocentric'. At Zürich, he spoke about the banded structure of the "primitive" [i.e. mainly Lewisian] gneisses. He compared it to layered magmatic intrusions, in the form of sills and laccolites, in the Tertiary volcanic rocks of the Western Isles, considering even some 
of the folding to be of primary origin. This hypothesis seems to have had few followers.

Auguste Michel-Lévy (1844-1911) was then the most influential French petrologist. On account of his imposing physical and intellectual stature, he was affectionately known as 'Moses'. His authority did not exclude a "fatherly kindness" to younger scientists (Lacroix, 1914). As Director of the Service de la Carte géologique de France he held a position similar to that of Geikie in Britain. Michel-Lévy propounded quasi-Cartesian "Principles to be followed for an universal classification of [igneous] rocks" (he had been first in his class at the École Polytechnique). Petrological studies of thinsections had already made considerable progress. Notably, it was becoming possible to determine the albite/anorthite ratio of plagioclase feldspars by optical means. For the origin of granites (including 'granulites' sensu gallico antiquo, i.e. leucocratic potassic granites with white mica) he invoked the action of volatile substances as minéralisateurs. This was a sort of prelude to the establishment of a 'French school' of granitizers, as opposed to the exclusively magmatic interpretation of a 'German school'. Half a century later, this was to lead to the great Granite Controversy.

Michel-Lévy upheld the view that petrological terms should be independent of the geological age of the rocks. The curious fashion of distinguishing young basalt from old diabase, or young rhyolite from old quartz porphyry, may have been a sort of relic from the times of Abraham Gottlob Werner, at any rate, it was chiefly favoured in the German-speaking countries.

Marcel Bertrand (1847-1907) was Professor at the École des Mines in Paris (see Trümpy and Lemoine, 1998). Ten years before the Zürich Congress, he had published his famous note on the Glarus Alps (see Section 1). In 1887, he had distinguished the Alpine, Hercynian (Variscan), Caledonian, and 'Huronian' chains, even pursuing them across the Atlantic into North and Central America. His figure of this correlation has been often reproduced.

The title of Bertrand's Zürich lecture was "On the structure of the French Alps and the recurrence of certain sedimentary facies" (CR, 161-177), but his paper was mostly devoted to the second subject. He proposed that a succession of four complexes could be found in all mountain chains: $(A)$ gneisses; $(B)$ predominantly pelitic formations or flysch schisteux; $(C)$ arenaceous flysch or flysch proper; $(D)$ red sandstones and conglomerates. $A$ and $B$ characterized the central part of the chain, within the geosyncline. $C$ was mainly restricted to "secondary geosynclines" in their external parts. $D$ was characteristic of basins surrounding the chain. The strong metamorphism of $A$, and the weaker one of $B$, was thought to be of primary, 'geosynclinal' origin. Each stage was supposedly accompanied by its own spectrum of plutonic and volcanic rocks. Granites, for instance, were mainly associated with A but could penetrate $B$. The gneisses $(A)$ were considered to be Permian in the Alpine, Devonian in the Hercynian, Cambrian in the Caledonian, and Archean in the 'Huronian' belt. Bertrand's article thus introduced a sort of 'comparative ontogeny' of mountain chains. It was certainly the most original and the most widely quoted paper of those presented at the Zürich Congress.

Eduard Suess (1831-1914) compared the Northern and the Southern Alps. As already stated, he did not provide a manuscript.

Albert Heim gave an overview on the geology of Zürich and of its surroundings $(C R, 181-197)$. He did not believe in the possibility of glacial over-deepening. According to Heim, the lakes on both sides of the Alps were due to the drowning of river valleys by a late subsidence of the Alps with regard to their forelands. His arguments documenting this hypothesis, such as supposed river terraces dipping towards the Alps, have been discredited. A fatal proof for glacial erosion took place in 1908, when the Lötschberg railway tunnel ran into water-logged gravels below an over-deepened valley, killing a number of workers and mine horses.

The communications in the section meetings were of unequal impact-but this was not the case for the 6th Congress only. Still, they were decidedly cosmopolitan, ranging from New Zealand glaciers to the centre of North America (where N. H. Winchell thought that Keweenaw and even Animikie belonged to the "Taconic Sys- tem", and were therefore of Early and Middle Cambrian age). There was even some experimental geology: Stanislas Meunier tried to prove that striated pebbles could form in mudflows and did not necessarily imply glacial origin.

August Rothpletz (1853-1918), from Munich, talked about "thrust faults and their methodical investigation" $(C R, 252-259)$. He referred to the early work by Arnold Escher in the Glarus Alps (see Section 1) and by the Rogers brothers in the Appalachians. He noted that thrusts were limited to folded mountain ranges, but that they were systematically younger than the folds. In the Glarus Alps, which Rothpletz knew well, this is indeed generallly true; folded thrusts had not yet been recognized. Somewhat artificially, Rothpletz suggested a conflict of generations: the hidebound older geologists saw overfolds where the younger ones recognized thrusts. " $D a$ hallt aus jugendlichen Kehlen der Ruf: hier auch gibt es Ueberschiebungen!" ("Youthful voices cry out: here as well there are thrusts"). We may suspect that Albert Heim, Rothpletz' senior by only four years, was not really amused.

A substantial part of the Compte Rendu (519-690) was devoted to the second edition of Eugène Renevier's Chronographe géologique. A supplement, with twelve colour plates, appeared in 1897. Renevier listed over 3000 stratigraphical names. Most of the chronostratigraphic terms were ones that are at present in use, though with some exceptions. In the Jurassic, his "Oxfordian" stage was subdivided into the substages Callovian(!), Divesian (early Oxfordian of present nomenclature), and Argovian. Likewise, his "Cenomanian" comprised Albian(!), Vraconnian, and Rotomagian.

The facies terms of the Chronographe are informative as to the state of sedimentology in 1894. Renevier divided marine terrigenous formations into "littoral" and "bathyal". Among the former, he included oolitic iron ores: he realized that iron "oolites" were quite distinct from the true, calcareous ooids. His "bathyal" fomations were essentially pelites, further characterized by their fossil content. The "zoogenic marine formations" comprised three facies groups. The "faciès pélagal" was characterized by fine-grained limestones, with cephalopods as well as with large and small foraminifera, and also by glauconitic limestones. The "faciès récifal" designs coral and rudist limestones, oolitic limestones, and dolomites. Renevier's list of "faciès abyssal" is rather surprising to us. He included under this heading not only bedded cherts, but also siliceous limestones and chalk with chert nodules. The term "rubigineux" was applied to various red-beds, some of which are possibly not even of marine origin The red deep-sea clays dredged by the early oceanographic expeditions (Murray \& Renard, 1891) may have led the author to regard red colour as a sort of guide fossil for abyssal environments. The "Chronographe" presumably soon became outdated. Nervertheless, it bears witness to the encyclopaedic knowledge of a professor at a small university with a good library.

If we take into account the contributions by Zittel, MichelLévy, Renevier, and even Bertrand, we get the impression that classification still was a major preoccupation for geologists at the end of the 19th century. This may be a rather boring aspect of our science; but it was a necessary step in order to establish a standard nomenclature of world-wide use.

\section{Excursions}

There were ten excursions: five to the Jura and parts of the Molasse Basin before, and five to the Alps after, the Zürich meeting. Two of them were physically easy, with transport by railway, lake-steamer, and horse-wagon or coach. Four alpine excursions were fairly strenuous, with up to $1,700 \mathrm{~m}$ uphill walking on slippery footpaths. During the week after the Congress, rain, fog, and early snow caused the leaders to make changes to the intended programme. Albert Heim and his party were blocked for a day in the hut near the top of the Säntis mountain, whiling away their time with "science, gymnastics, and humour"[!]. 
Registration for the excursions was uneven. Until a few days before the deadline, nobody was interested in Rollier's Jura trip. However, Heim's excursion to the Alps of eastern Switzerland was soon overbooked, and five younger Swiss geologists were requested to step aside in order to accommodate important foreigners.

Heim's bugbear, August Rothpletz, also wanted to join this field trip. This made the Zürich professor throw a tantrum. He wrote to Renevier (draft in the ETH archives):

Concerning the inscription of Rothpletz, I take the legal standpoint: 1) In 1883, R. has broken off all personal relation with me. He wants to come to the excursion in order to confront his opinions with mine. I also have the right and the obligation to defend myself-travelling together for twelve days in the mountains is not possible without personal contact. Therefore he must not participate. 2) I am not employed by the Congress to lead the excursion but I have offered to do it, and therefore I am not obliged to take everybody with me; it is my right to say whom I want and whom not! 3) It is my duty to reject $R$. because his presence is painful for many of the participants and the whole excursion might end up in a quarrel-I cannot take a madman [Verrückter] with me.4) If $R$. were to be present, I myself might soon fall ill and would have to break off the excursion, a risk for the other participants which I cannot assume.-I declare that I shall not lead the excursion if $R$. is to come, [even if] I am aware that I might be forced to do it.

In several letters, Renevier tried to settle the dispute.

As to $R$., this is a more delicate question ... You cannot refuse him ... I need not mention your personal relationship ... I still hope to eliminate $R$....R. replies that he wants to come precisely in order to defend his ideas ... R. finally renounces, but he will not register for another excursion [instead].

It took Karl A. Zittel's diplomatic skill to persuade Rothpletz. "[Zittel] has advised [i.e. forced, with all his Munich authority] R. to withdraw his registration ... . he is glad to have succeeded".

So this was the way in which a scientific controversy was handled. Anyone who dared criticize the (absurd) hypothesis of the double fold was by definition a madman, unless he was a distinguished professor, like Marcel Bertrand; in this case his ideas were not discussed but simply ignored.

The excursions to the Jura Mountains were greatly concerned with stratigraphic problems. Friedrich Mühlberg's map and sections in the northern Jura are excellent. They probably also contain observations by Friedrich's son Max, who acted as secretary during his father's excursion. Naturally, Friedrich Mühlberg wrote about thrusts and klippen (in the present sense). Well in advance of his time, he realized that the folds were detached along the "slippery gypsum" (schlüpfriger Gyps) of the Triassic. Mühlberg taught at the Kantonsschule (senior high) at Aarau, in northern Switzerland. A year after the Zürich Congress, he would find a new pupil in his class, a German-born Jewish boy, strong in mathematics and sci- ence. Albert Einstein (see 1987) had kind memories of the Aarau school and especially of his teacher Friedrich Mühlberg, whom he called "ein origineller und interessanter Kerl" (an original and interesting fellow; letter to Emil Ott, 23 October, 1946). However, Einstein's interest in geology was limited. During a field trip to the Jura, Mühlberg asked him whether the oldest strata were normally found at the bottom or at the top of a sequence. Young Einstein replied: "ist mir ganz egal" (I couldn't care less).

At the other end of the scale of tectonic understanding, we find the 'pure' stratigrapher Louis Rollier, who drew the Mont Terri anticline (near the Swiss-Alsatian Border), which is clearly overthrust northwards, as a flat, symmetrical fold.

In the Alps, Albert Heim $(L G, 97-110)$ still firmly upheld the double fold theory (see Figure 2), although his excellent observations implied that all visible (as opposed to conjectural) folds had axial planes inclined to the south and were facing northwards. There is no indication that his conversation with Suess in 1892 might have mellowed his assurance. The papers by Bertrand and by Rothpletz were not mentioned at all.

The part of the guide-book (111-158) devoted to Schmidt's excursion in central Switzerland is revealing for the state of alpine tectonics in 1894 (see Figure 3). Schmidt still drew the (present) Helvetic nappes along the eastern shore of Lake Lucerne as rooted mushroom folds, following Heim (1891). On the other hand, he did realize that the Triassic and Jurassic rocks of the Mythen, further north, floated off Tertiary flysch and were thus part of a nappe. But unlike Schardt (1893), who derived this nappe far from the south, he made it come from the north, over a much smaller distance. He thought that a mythical and now buried 'Vindelician Chain', between the Alps and the Molasse Basin, had shed the Mythen nappe and exotic boulders in the flysch southwards, pebbles in the Molasse conglomerates northwards. Up to 1900 , only a few other workers followed Schmidt's interpretation.

The year 1894 witnessed a minor uproar, concerning the age of the Hochgebirgskalk (High Mountain Limestone) in the Bernese Oberland. These thick grey limestones lie conformably on the thin Zwischenbildungen (Intermediate Formations, Triassic and fossiliferous Middle Jurassic), which in turn rest unconformably on basement gneisses of the Aar Massif. It was accepted that the Hochgebirgskalk was essentially of Late Jurassic age. But in March 1894, Henri Golliez came forward with the contention that these limestones were Triassic and thus overthrust on the Zwischenbildungen. This would have radically changed the views about the structure of the entire chain. The lower mountains (e.g. Männlichen) north of the high chain are formed by Jurassic rocks, with a facies development differing from that of the Zwischenbildungen, and Golliez supposed that they belonged to a great recumbent fold of which the 'Triassic' Hochgebirgskalk was the core. This was a 'modern' idea, based on erroneous data. Such things happen. Heim and Baltzer protested

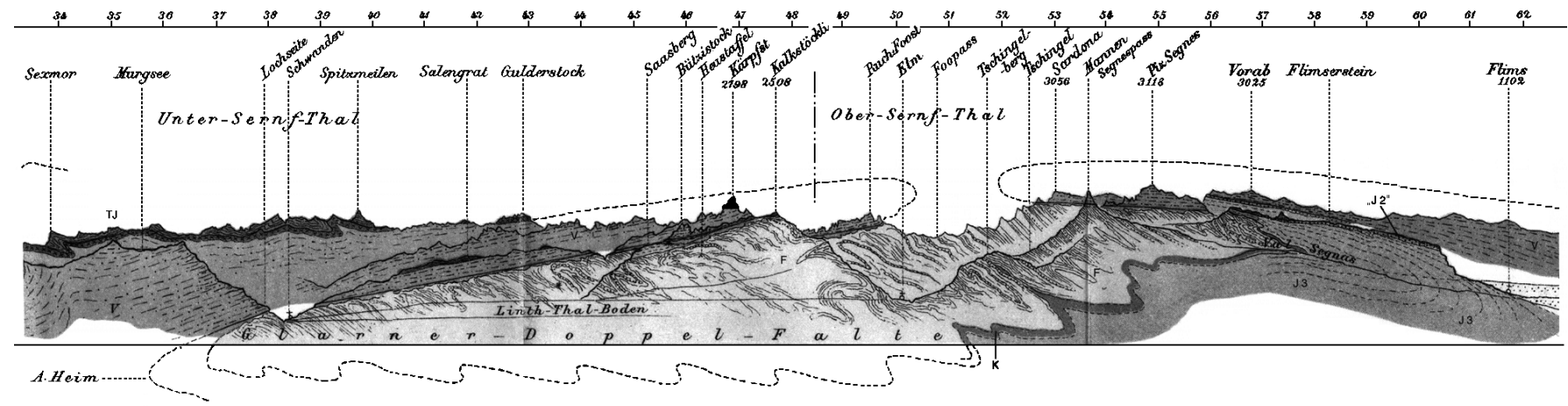

Figure 2 Section through part of the Glarus Alps, by Albert Heim. The numbers give km from the northern end of the section. From LivretGuide Géologique, 1894, Plate VII. V: Permian Verrucano; TJ: Triassic and Lower Jurassic; “J2”: supposed Middle Jurassic (in fact, Cretaceous); J3: Upper Jurassic limestones, including the Lochseitenkalk mylonite; K: Cretaceous; : Eocene to Lower Oligocene flysch; This section shows the absurdity of the Double Fold hypothesis: all the visible folds below the thrust and above the thrust (e.g. on Sexmor and Spitzmeilen) are facing north; the gap at the col of Foopass is far too narrow to accommodate the fronts of the two 'facing' folds, where the Mesozoic sediments should be thickest. 
N. s.

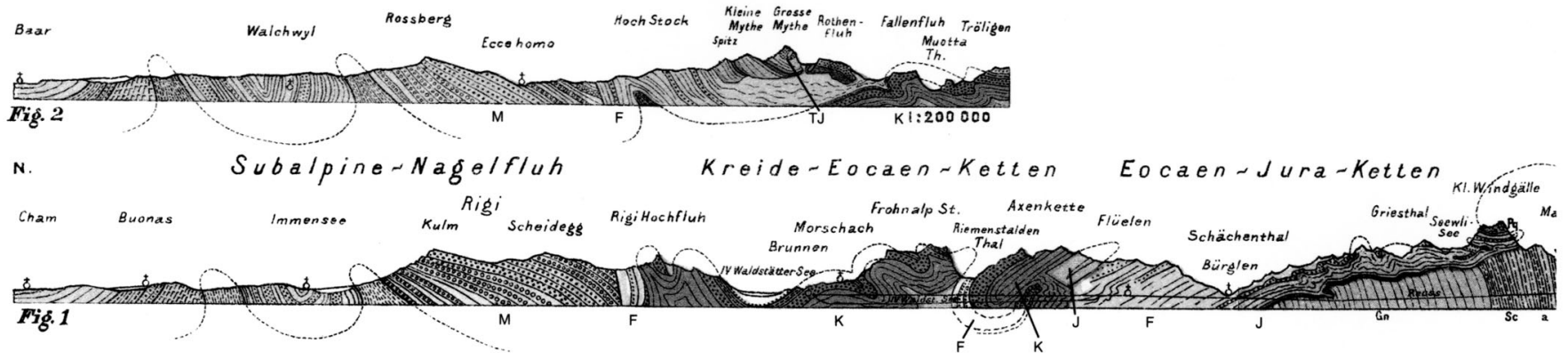

Figure 3 Part of a section through the Alps of Central Switzerland, by Carl Schmidt (Livret-Guide Géologique, plate VIII). Gn: etc. basement rocks; J: middle and (mainly) Upper Jurassic; K: Cretaceous; F: Flysch (Eocene; some K, not recognized in 1894); M: Molasse (Oligocene and Miocene); The Triassic and Jurassic rocks of the Mythen (Spitz, Kleine Mythe, Grosse Mythe, Rothenfluh) are clearly shown as outliers of a nappe (supposedly derived from the north), whereas the [Helvetic] chains of Cretaceous rocks are still interpreted in an 'autochthonist' manner.

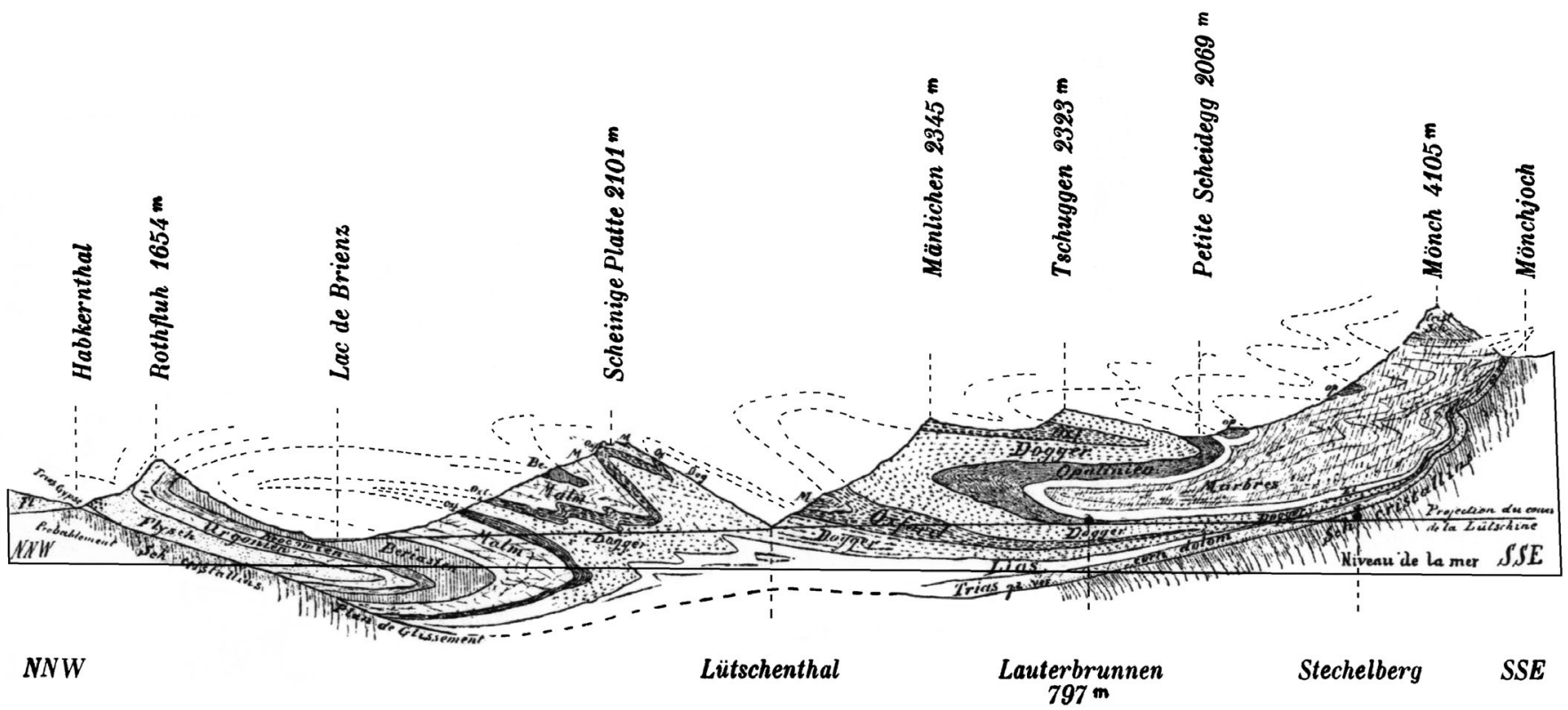

Figure 4 Section through the Bernese Oberland, by Henri Golliez. From Livret-Guide Géologique, 1894, Figure 67, p. 210. The recrystallized limestones (Marbres, marbles), e.g. in the north face of Mönch, were thought by Golliez to represent the 'Triassic' core of a north-facing recumbent fold. In fact, they are of Upper Jurassic age, and Eocene rocks separate them from the 'Opalinien' (= Aalenian shales) and 'Dogger' (Middle Jurassic) of the Helvetic nappes.

loudly and asked Renevier that the corresponding figures in the guide-book be withdrawn. But they had already been printed and were reproduced $(L G, 207$ and 210$)$, although without mention of the age of these limestones (see Figure 4). The participants of Baltzer's excursion, particularly a party of stratigraphers, led by Eberhard Fraas, from Stuttgart, fully confirmed the Late Jurassic age of the Hochgebirgskalk (CR, 468-472).

Golliez's 'Triassic hypothesis' only survived for a few months. Already on 2 October, 1894, Renevier informed Heim that nummulites had been found in rocks above the Hochgebirgskalk, and that the latter was definitely Upper Jurassic. A note by Golliez (1896), strongly supported by Lugeon, stated that the presence of these Tertiary rocks below the Jurassic formations of the Männlichen group implied that the latter did belong to a great overfold [Helvetic nappe], thrust from south to north. Golliez referred to Bertrand's 1884 paper.

Schardt's excursion to the Alps of western Switzerland had few participants. The description in the guide-book clearly outlines the far-travelled character of the two Prealpine nappes (Médianes and Breccia). The facies differences between the external and internal parts of the Médianes nappe are well explained. In the innermost, metamorphic part of the Alps (Simplon region), the north-facing recumbent fold of the Antigorio nappe was recognized, whereas the Monte Leone basement rocks, to the north of it, were still considered as rooted. Schmidt drew a similar, though not identical, picture. Only during the construction of the Simplon Railway Tunnel (starting in 1898) did Schardt and Schmidt realize that Monte Leone, as well, was a basement nappe lying in a synform on Mesozoic calcareous schists.

Renevier and Golliez led the 'comfortable' round trip through the Alps. Renevier thought that Schardt's Prealpine hypothesis was not really necessary. Some of Golliez' drawings (e.g. $L G, 221$ ) are very suggestive: in the Dent de Morcles section, he recognized 'Caledonian', Variscan and Alpine structures. The jovial, paunchy (bedonnant) Golliez was also a gifted caricaturist.

The participants of the five alpine excursions finally met at Lugano, in the far south of the country. In the picturesque village of Morcote, toasts were drunk (lemonade for Heim and Schardt) to Switzerland, to the ladies, and to the forthcoming Moscow Congress of 1897.

Heim resigned his professorship in 1911 . He was sorely disappointed that the unbeloved Schardt was chosen as his successor, but 
he went on to write his admirable Geology of Switzerland (1919-1922). Lugeon became the Grand Pontiff of nappe tectonics. Both he and Heim collected numerous medals and honorary degrees. Hans Schardt who, along with Marcel Bertrand, had really discovered the Alpine nappes, received no such distinctions.

\section{Acknowledgements}

We thank Michel Durand-Delga and Marc Weidmann for information on A. Michel-Lévy and H. Golliez, Urs Gerber for the photographs, and David Oldroyd for looking over the English.

\section{References}

Bertrand, M. 1884. Rapports de structure des Alpes de Glaris et du bassin houiller du Nord: Société Géologique de France Bulletin, 3rd series, v. 12 , pp. 318-330.

Compte-Rendu Congrès Géologique International $5^{\text {me }}$ session, Washington, 1891: Washington, Imprimerie du Gouvernement 1893, 529 pp.

Compte-Rendu Congrès Géologique International, sixième session, en Suisse: Bridel, Lausanne 1897, 710 pp.

Einstein, A. 1987. The early years 1879-1902, ed. John Stachel, The Collected Papers of Albert Einstein: Jerusalem and Princeton University Press. v. 2, pp. 11, 217, and 276.

Geikie, A. 1897. The Founders of Geology: New York, Macmillan.

Golliez, H. 1894. Géologie de la chaîne des Hautes Alpes bernoises: Archives sciences physiques et naturelles, 3rd series, v. 30, p. 2

Golliez, H. 1896. La téctonique des chaînes de 1'Oberland bernois: Archives sciences physiques et naturelles, 4th series, v. 2, pp. 1-4.

Heim, A. 1878. Untersuchungen über den Mechanismus der Gebirgsbildung im Anschluss an die geologische Monographie der TödiWindgällen-Gruppe: Basel, Schwabe v. 1 (348 pp.) and v. 2 (246 pp.).

Heim, A. 1891. Geologie der Hochalpen zwischen Reuss und Rhein: Beiträge zur geologischen Karte der Schweiz., 25, 2 vols, 503 and 76 pp.

Heim, A. 1895. A. Rothpletz in den Glarneralpen: Vierteljahrsschrift der Naturforschenden Gesellschaft in Zürich, 40. Jg, pp. 33-70.

Heim, A. 1919-1922. Geologie der Schweiz: Leipzig, Tauchnitz, v. 1(1919) 704 pp.; v. 2/1(1921) 476 pp.; v. 2/2 (1922) 541 pp.
Lacroix, M. A. 1914. Notice historique sur Auguste Michel-Lévy. Liste bibliographique des travaux scientifiques de Michel-Lévy: Paris, GautierVillars et Cie., $52 \mathrm{pp}$.

Livret-guide géologique dans le Jura et les Alpes de la Suisse: Congrès géologique international, 6ème session Zürich, 1894, Paris, Alcan et Lausanne, Payot, $306 \mathrm{pp}$

Lugeon, M. 1902. Les grandes nappes de recouvrement des Alpes du Chablais et de la Suisse: Société géologique de France Bulletin, 4th series, v. 1 (1901), pp. 723-825.

Masson, H. 1976. Un siècle de géologie des Préalpes: de la découverte des nappes à la recherche de leur dynamique: Eclogae geologicae Helvetiae, v. 69 , no. 2 , pp. $527-575$.

Milanovsky, E. E. 2004. Three sessions of the International Geological Congress held in Russia and the USSR (1897, 1937, 1984): Episodes, v. 27 , pp. 101-106.

Murray, J. and Renard, A. F. 1891. Report on deep-sea deposits based on the specimens collected during the voyage of H.M.S. Challenger in the years 1872 to 1876: London, Eyre \& Spottiswoode, 525 pp.

Renevier, E. 1897. Annexe contenant les 12 grands tableaux en couleurs de Chronographe Géologique: Lausanne, Bridel.

Rothpletz, A. 1883. Zum Gebirgsbau der Alpen beiderseits des Rheines: Zeitschrift der Deutschen Geologischen Gesellschaft, Jg. 1883, pp. 135-189.

Rothpletz, A. 1894a. Ein geologischer Querschnitt durch die Ost-Alpen, nebst Anhang über die sog. Glarner Doppelfalte: Stuttgart, Schweizerbart, $268 \mathrm{pp}$.

Rothpletz, A. 1894b. Geotektonische Probleme: Stuttgart, Schweizerbart, $175 \mathrm{pp}$.

Schardt, H. 1893. Sur l'origine des Préalpes romandes: Eclogae geologicae Helvetiae, v. 4, pp. 129-142.

Schardt, H. 1898. Les régions exotiques du versant nord des Alpes suisses (Préalpes du Chablais et du Stockhorn et les Klippes), leurs relations avec l'origine des blocs et brèches exotiques et la formation du Flysch: Société Vaudoise sciences naturelles Bulletin, v. 34, pp. 114-219.

Trümpy, R. 1991. The Glarus nappes: a controversy of a century ago, in McKenzie, J. and Müller, D., eds, Controversies in Modern Géology: Academic Press Ltd., pp. 385-404.

Trümpy, R. and Lemoine, M. 1998. Marcel Bertrand (1847-1907): les nappes de charriage et le cycle orogénique: Compte rendu de l'Académie des Sciences, Paris, Sciences de la Terre, v. 327, pp. 211-224.

Zittel, K. A. 1899. Geschichte der Paläontologie bis Ende des 19. Jahrhunderts: Oldenburg, München und Leipzig, xi + 868 pp.

\title{
CALL FOR PAPERS
}

Episodes is the quarterly science and news journal of the International Union of Geological Sciences (IUGS). It focuses on the publication of results of scientific research and other information addressing issues of interest to the global earth-science community. Special emphasis is given to topics involving geological aspects of population growth and economic development and their resulting impacts on or implications for society. As the principal publication of the IUGS, Episodes also carries information about IUGS scientific programs and activities to the extent necessary to communicate effectively with the worldwide IUGS constituency.

Contributions of the following types of manuscripts are here solicited:

- scientific articles

- conference reports

- news and views

- letters to editor

- book reviews

- information on training courses (especially those geared to participants from developing countries)

- noteworthy new publications, including national or regional geologic maps

Episodes also invites photos or other images for the front cover. Photos must be of high technical quality and tell an interesting geological story. A color transparency and one color print (at least $9 \mathrm{~cm} \times 12.6 \mathrm{~cm}$ ) are required for submission, which should be supplemented with a short explanatory paragraph (no more than 100 words).

Please address all contributions to:

\author{
The Editor \\ Episodes \\ P. O. Box 823, 26 Baiwanzhuang Road \\ 100037 Beijing, CHINA \\ Tel: +86-10-68320827, +86-10-68329084 \\ Fax: +86-10-68328928 \\ E-mail: episodes88@yahoo.com
}

